\title{
PSYCHOLOGICAL WELL-BEING OF MEDICAL STAFF IN KOSOVO PRISONS
}

\author{
Mr.sc. Valbone Ramaj Phd candidate \\ Msc. Arber Zeka \\ University Vizion, North Macedonia \\ University "Hasan Prishtina", Prishtina
}

\begin{abstract}
The nature of work in the face of constant stress, influences work performance, especially the medical staff in prisons, who are still involved in chronic patient problems, this makes this staff emotionally affected and cause problems of a depressive and anxiety nature.

The study investigated the psychological well-being of health staff in prisons in relation to the profession and professional responsibility, taking into account the workplace.

The study is a descriptive study with strong elements of quantitative statistical analysis, related to stress and psychosocial factors of stress in health workers.

The findings of this study show that working conditions in the prison sector in Kosovo are not satisfactory, in terms of the level of psychological well-being, I take into account the pressure of the category in which we work.

Our study provided very detailed data on psychosocial factors in the workplace among health workers in our country.

Social relations, social support and a sense of community, we suggest that these aspects be strengthened. But this situation should not be imposed on the work environment and become a cause for circumvention or violation of various criteria or procedures which are necessary for the proper functioning of the work.
\end{abstract}

\section{INTRODUCTION}

Psychological well-being as a term and concept is a theory developed by Carol Ryff that defines six factors that contribute to the psychological well-being, satisfaction and happiness of the individual (Seifert, 2005). Psychological well-being consists of positive relationships with others, personal mastery, autonomy, purpose and understanding of living, and personal development (Ryff, 1989). Psychological well-being is achieved by achieving a state of equilibrium influenced by challenging and rewarding life events (Dodge et al., 2012). The term is used in health as a comprehensive sentence meaning pleasure, satisfaction with all elements of life, actualization (a sense of achieving something with life), peace and happiness (SOSP, 2010).

Indeed, the deepest philosophical roots of this theory are found in Aristotle's formulation of the highest human good, which in his Nicomachean Ethics (Oxford University Press, 2009), he called eudaimonia (Greek word translated usually as happiness or well-being). His writings then clarify the meaning of this alternative approach to well-being (Ryff, 2006) by claiming that the highest of all human goods is not happiness, feeling good, or satisfying appetites. Rather, it is about spiritual activities that are in line with virtue, which Aristotle elaborated to mean the pursuit of the best that is within us.

Two centuries later, these ideas flowed naturally into the humanistic and developmental concepts of self-realization. Existing thought, on the other hand, stressed the importance of finding meaning in adversity or in an absurd world. From a scientific point of view, the biggest point was that welfare research, if it is to do justice to the topic, should include aspects of making sense, self-realization, and the endeavor of being human.

Psychologists use the term well-being for the type of happiness that is based on the meaning, purpose, and fulfillment of potentials. Research and practices on psychological well-being have identified six important components (Baer, 2014). 


\section{GENERAL CONTEXT}

Work is important to most of us on many levels. Doing a job that we enjoy and enjoy can give meaning to our lives, especially our material income from the work we do, as our standard of living depends on the money we make, while employment often contributes to ourselves. -our image and self-esteem. Yes not everyone has the opportunity to work in a rewarding and challenging job. $85 \%$ of employees worldwide, admit that they hate their jobs, anonymously surveyed, according to a Gallup (2017) survey. "A lot of people in the world hate their job and especially their boss," the report says. In 2013, Susan Adams for Forbes magazine reported in a poll, saying that "work is more often a source of frustration than fulfillment for nearly $90 \%$ of the world's workers."

Common causes of work stress include long hours, heavy workload, job insecurity and conflicts with co-workers or bosses (Nekoranec and Kmošena, 2015). Work-related problems can affect our physical, emotional, and mental health. Common issues that influence our health at work (Harnois and Gabriel, 2002) include job dissatisfaction, workplace injury, stress, discrimination and harassment, violence, accidental death, and retirement.

Some jobs pose a greater health threat than others. For example: a person working night shifts is at greater risk of a range of disorders, accidents and other effects. Psychosocial risks and work-related stress according to the European Agency for Safety and Health at Work (EU-OSHA, 2013) are among the most challenging issues in occupational safety and health. They significantly affect the health of individuals, organizations and national economies. When workers experience stress in their workplace as a result of their work demands being excessive and greater than their ability to cope with them. In addition to mental health problems, workers suffering from stress at work may continue to develop serious health problems which may include obesity, cardiovascular disease, gastrointestinal problems, transportation accidents, work accidents, family problems, and divorce.

\subsection{Mental health and workplace stress}

Mental health problems are a burden and the biggest contributors to disease worldwide (MHF, 2000). In this regard, it is increasingly understood that employees' mental health is a crucial determinant of their overall health and that poor mental health and stress in the workplace can be a contributing factor to a range of physical ailments: hypertension, diabetes and cardiovascular problems etc. There is an extensive literature on the relationship between all aspects of life and the workplace impact on health and an increasing evidence base on the importance of psychosocial factors in the workplace (Robert \& Theorell, 1990; Marmot \& Bobak , 2005; Marmot \& Wilkinson, 2006; Marmot et al, 1991; Siegrist et al, 2004; Stansfeld et al, 1998; Wilkinson \& Marmot, 2003).

Although no EU country has specific rules on workplace stress, the general legal frameworks of all countries refer to psychosocial risk factors that can cause or exacerbate workplace stress (Kuhn, 2010). ). Psychological effects such as anxiety and depression, loss of concentration and poor decision making are also contributing to the weakening of our health. In addition, poor mental health can also lead to burnout at employees, seriously affecting their ability to contribute meaningfully to their personal and professional lives (WHO, 2005).

Mental health problems affect functionality and work capacity in many ways. And that also some professions are more at risk of mental health problems than some others. The healthcare professions are among the top six stressful (Cooper et al., 1988). But it should also be noted that not all health professionals develop the same level of stress and not all of them develop signs of occupational burnout. According to a study conducted by Foxall et al (May, 1990), the medical (nursing) staff of the Intensive Care Unit reports that dealing with the treatment of nearly dead patients is their first source of stress, compared to nurses working in the Interno medical ward or those of the Surgery ward. According to other studies, surgical nurses value the emotional aspect as little as possible compared to their colleagues in the oncology and hematology departments (Tyler and Ellison, 1994). 
Healthcare professionals are generally more prone to problems with occupational stress and burnout, being in some ways also responsible for human life and their actions (Sapountzi et al, 1994). In this regard, Riggio (2003), in his study, has found that the impact of stress at work negatively affects employee satisfaction and leads to poor health as it is believed that half of all physical ailments are related to stress. Acting as a silent or invisible killer, workplace stress has been responsible for $80 \%$ of all modern illnesses, according to the National Institute of Occupational Safety and Health (NIOSH, 1999). Every year, the World Health Organization marks "World Mental Health Day", through which it tries to emphasize the importance of maintaining mental and physical health.

The theme of World Mental Health Day 2017 was precisely "mental health in the workplace". As the WHO explains on its website, people spend most of their time at work each week and as a result, "our work experience is one of the factors that determines our overall well-being." Simply put, problems at work can haunt you at home, and problems at home can haunt you to work.

\subsection{Prison work and psychological well-being}

Bottoms (1999) describes prison as a world completely separate from the outside world, where structured daily life prevails, environment dominated by empathy, where strict routine prevails a particular social climate, where the execution of the daily routine is crucial to maintaining the required condition, an environment where the relationship between prisoners and prison staff is a key element for the successful implementation of the daily routine, and an institution which with its specific methods made the maintenance of order. In this regard Liebling (2011) writes that the relationship between prison staff and inmates represents the heart of a prison beating. However, the development of relationships between different actors in an institution such as a prison is rigid, as the possession of power and authority is concentrated in the hands of one group (prison staff) and the other group (prisoners). it is in the role of listener and submissive, at least that is how they see themselves. Based on these conditions, the relationship between prison staff and inmates is formed with more effort and difficulty, with more negative intensity than cooperative and progressive (Weinrath, 2016).

Prisons are not positively associated with mental health (WHO), and as the literature shows, people working within uniformed services are at particular risk of experiencing work-related stress (Downden and Tellier, 2004). According to Johnson and colleagues (2005), the profession of a prison maid is one of the six occupations in which the workplace has an impact on deteriorating mental and physical condition. For correctional officers, prison work is fraught with confrontations, deception and force, a very challenging job physically and that constantly tests the integrity of correctional officers (Miciel, 2008).

Rogers (2001) surveyed correctional staff to learn about their stress levels, mental health, and risk behaviors. In terms of their mental health, Rogers found surprising rates of depression, feelings of hopelessness, and suicidal thoughts. $25 \%$ of correctional officers reported feeling a lack of emotional response, $20 \%$ reported finding no satisfaction in anything, and $13 \%$ reported a lack of hope or felt worthless. In terms of suicidal thoughts, "3\% have reported thoughts of ending their lives at least once a month, and an additional 6\% report these thoughts 1-2 times over the last six months.

One of the other most vulnerable groups is prison health staff. The same social, health and economic changes as correctional officers affect prison health staff. Doctors also suffer from mental illness and, in fact, have higher rates compared to the patients they see. A study conducted by Medical Protection (2015), found that $85 \%$ had experienced some kind of mental health problem, this in terms of the work of health staff in general. Problems related to prison work and mental health when it comes to health staff have not yet been well studied and there is very little information. Prison health staff are the "heart and soul" of most prisons, so it is important to explore the way work affects them. Stress at work, specific work commitments and organizational commitment are three important areas in which the work environment can affect the health staff of a prison. Work stress is usually defined by the literature examining correctional services issues such as feelings of tension, anxiety, and work-related frustration (Cullen et al., 1985; Grossi et al., 1996). 


\subsection{Prison health staff}

The health staff, the services they provide are fraught with uncertainties and limitations. The patient and the doctor do not choose each other, and that the prison environment can compromise patient autonomy, privacy, confidentiality, and even the ability to avoid harm (Restellini, 2008). The whole working day is filled with uncertainty in the workplace. Moreover, they are exposed to biological hazards as a result of contact with communicable diseases in prison, especially tuberculosis and AIDS (Jaskowiak and Fotana, 2015). Health staff should treat prisoners, first and foremost, as patients and not as prisoners. Health staff should have the same professional independence as their professional colleagues working in the community. Prison health policy should be integrated into national health policies, and public health administration should be closely linked to prison-administered health services (Gjocaj, 2015).

Doctors and especially health staff working in prison should see the prisoner as an individual with personal needs (not as a criminal), with rights to privacy and confidentiality, and still leave room for autonomy in decision-making. for personal health care. However, security personnel escort the prisoner to the doctor, so the real opportunity to maintain patient confidentiality or confidentiality is compromised. Usually, a physician should advocate for the patient, prevent harm when possible, and keep the patient's interests above his own. Suspicion of correctional staff and hostility towards prisoners have the potential to color any medical appointment. All these specifics that a health worker should keep in mind, definitely produce an amazing stress pressure being positioned between two main actors, on the one hand the correctional service with its specifics and on the other hand the prisoners who have the right to access health care or to maintain the specific medical ethics and standards that are necessary in prison should not be neglected. Staff should also be able to put on signs of serious illness and be experts in first aid and managing mental health crisis situations (Fraser, 2006). It is a proven fact that working under certain circumstances makes people more sensitive to stress and this can lead to serious health problems such as depression, anxiety, mood disorders and personality disorders (Molleda et al., 2015), among others, all staff should be aware of what health staff can do and may be required to do, but also activities in which health staff should never be involved (WHO, 2008).

\section{PRISONS IN KOSOVO}

Execution of imprisonment in Kosovo has its own path of development and transformation. The means and methods of execution of this sentence and the way of treatment of convicted persons during their stay in correctional institutions, from the creation of the state until today, depended on certain historical, social, economic, political, ideological circumstances. , as well as by the very purpose of serving this sentence. To better understand the prison system in Kosovo, we need to know that currently the prison system in Kosovo has two institutions which are responsible for the correction and supervision of convicts, as long as one of them is fully responsible for each element that connects with the serving of sentences to prisoners based on laws, the health part and everything related to health belongs to the Health Department of Prisons.

\subsection{Kosovo Prisons Health Department}

The health care service in the prisons of the Republic of Kosovo is organized and functions as an integral part of the health system of the country, due to the specifics it is organized and supervised by the Health Department of Prisons (DSHB) under the Ministry of Health. The duties and responsibilities of this department are:

1. Monitoring and management of the work of health institutions in prisons ( 8 ambulances, 2 health stations, 1 institution for health care for people with special needs and 1 health institution for mother and child care);

2. Application of international standards for the protection of human rights in the health aspect;

3. Providing professional advice on difficult-to-manage cases and cases requiring multidisciplinary and cross-sectoral treatment; 
4. Support in the management of complicated situations in prisons which are related to health such as hunger strikes, attempted suicides, violence in prisons, deaths in prisons, etc.

The Prisons Health Department has 122 regular medical staff (general practitioners, psychologists, dentists, psychiatrists and nurses) and 16 specialist medical consultants in various fields. A good health system in prisons produces significant benefits for society, which in this way also prevents the further spread of disease. But the very presence of multiple infectious diseases and the frequent cases of psychiatric problems, are elements that cause dissatisfaction of those who provide these services but also especially influence similar symptoms to other members who can be considered healthy (Andrew Coyl, 2004 ).

Prison health staff are responsible for caring for prisoners or detainees, and have a duty to provide them with care in protecting their physical and mental health. In particular, they have a duty to provide services with the same standards as those provided to non-prisoners and especially to ensure that their primary duty to any prisoner who is a patient remains a clinical duty and should never be considered otherwise. The health care system in prisons generally faces a large number of problems; compared to the general population, inmates are more likely to have clinical problems, such as airborne infections, commonly used injectables, depression concerns, and other mental health problems.

Common health problems in prisons, according to Andrew, 2006, are:

1. Addiction (Drugs, Alcohol, Tobacco)

2. Infections

3. Chronic disorders (lung diseases, heart, diabetes, epilepsy, cancer, diseases of the reproductive system, etc.

4. Low mood and self-esteem (self-esteem, addiction, alcohol and drugs

5. Concerns.

6. Depression.

7. Severe mental disorders.

\subsection{Functioning of health services in Kosovo prisons}

The Health Department of the prisons through the health units of the prisons in the health institutions of the prisons performs tasks which are related in relation to the type and the way of functioning of the correctional institutions and the regime and the legal status of the prisoners.

Health services based on prison procedures (PSV, 2017), are: First medical visit and file opening; Regular visits; Systematic visits; Specialist visits; Required visits; Isolation visits (solitude); Visits of prisoners refusing food; Visits of prisoners refusing health treatment; Supplementary medical visits; The last medical visit of the prisoners to the prison.

The specific indicators that are followed in prisons are:

1. The injuries themselves

2. Bodily injuries

3. Sexual abuse

4. Hunger strike protocol

5. Managing cases of risk for suicide

6. Death in prison

All these services are regulated by special protocols, while the medical service for prisoners is provided during the entire period of imprisonment.

\section{IMPORTANCE OF THE STUDY}

The importance of this study is to investigate the relationship between psychological well-being and the workplace, while the research results have helped us to see the essential implications of psychological well-being with the workplace and 
routine tasks of health workers in prison, which do not only affect mood of the individual, but also in his health well-being in general, things which will be argued in the conduct of this research.

This will be the first study in our country that has multi-plan researcher the impact of the workplace (stress) on health workers in prisons. More specifically, this study will measure the level of dimensions (or different psychosocial factors) of stress, detailing them by context and level of work (work environment, tasks, interpersonal relationships and leadership, workindividual interaction, and individual context, health and well-being).

Each context and level is detailed in finer levels, including quantitative, cognitive, emotional requirements, degree of job freedom, community feeling, job insecurity, job satisfaction, general health, mental health and more, covering thus almost all psychosocial factors that may play a role in psychological well-being and the nature of the workplace.

\subsection{Purpose and Objectives of the research}

The purpose of the study was to explore the risk and protective factors related to the level of psychological well-being at work reported by prison health workers in Kosovo. Identifying and defining the links of psychological well-being with sociodemographic factors (age, gender, level of education and socio-economic factors of the subjects in the study). Identify and determine the relationship of the dimensions of stress in the workplace with other independent factors in the study (occupation, place of work, nature of work and time of exercising the profession).

\subsection{Research Questions}

The study tends to identify protective and risk factors (age, gender, level of education and socio-economic factors, occupation, place of work, nature of work and time of exercising the profession) that are related to the psychological environment (depression and anxiety) of staff working in Kosovo prisons.

\subsection{Hypotheses}

Hypothesis _1: There is a positive correlation between mental health problems like anxiety, depression with the level of well-being reported by prison staff.

Hypothesis_2: There is a positive correlation between health problems like headaches, high blood pressure, heart problems with the level of stress reported by prison staff.

\section{STUDY METHODOLOGY}

The study is a descriptive study with strong elements of quantitative statistical analysis, related to stress and psychosocial factors of stress in health workers. This study describes the socio-demographic characteristics of health workers, prison medical staff, who are involved in a unique work environment and especially the emotional impact of this workplace. In order to achieve the objectives of this study, quantitative methods of data collection were used, where through the instrument were collected information related to psychosocial stressors in health workers in prisons. Above all, the present study highlighted the importance of additional aspects of control, such as discretion of skills, flexibility of schedule, and the ability to take a break when required, in support of work-related psychological well-being in correctional settings. This has highlighted the importance of adequate leave for employee well-being and job satisfaction. Adequate time for rest and recovery during the work day is likely to be essential for people working in critical safety jobs who need to maintain a high level of vigilance. The study concludes that urgent action needs to be taken to improve the mental health of prison health 
staff in Kosovo, and that attention to improving labor relations, the right role and reducing demand would be the effective starting point.

\section{STUDY FINDINGS}

The findings of this study show that working conditions in the prison sector in Kosovo are not satisfactory, in terms of the level of psychological well-being, I take into account the pressure of the category with which you work. Levels of mental health problems and job satisfaction were significantly higher. The information obtained has a strong potential to inform interventions to improve the well-being of prison health staff and provide the basis for further investigations, which will provide a supportive result in relation to the psychological well-being of this population.

- Above all, research has argued that, there is a positive correlation between mental health problems such as anxiety, depression with the level of well-being reported by prison staff. Take into account the high level of Depression, with $4 \%(\mathrm{~N}=5)$ of the sample at the level of severe depression and $1 \%$ extremely severe, followed by anxiety with $16 \%(\mathrm{~N}=17)$ of the sample at the level of anxiety of aggravated and $8 \%$ extremely aggravated. Also the high level of stress presented in dimensions such as concealment of emotions, freedom at work, role uncertainty, social relationships, job insecurity, mental health, vitality, behavioral stress, as well as somatic and cognitive stress. The current study, however, identified additional risks, such as ambiguity of goals in life and positive relationships with others.

- There is a positive correlation between health problems such as headaches, high blood pressure, heart problems with the level of stress reported by prison staff, argued through somatic stress (average 2.61) and cognitive stress ( average of 1.94).

\section{CONCLUSION}

The current study on the psychological well-being in the workplace of prison health staff serving in Kosovo prisons, for the first time provided a comprehensive overview of the workplace issue. Our study also provided very detailed data on psychosocial factors in the workplace among health workers in our country, analyzing demographic, social and economic characteristics, as well as the type of profession, place of work and duration of experience. In work.

To understand in detail the stress at work and the psychological well-being associated with the workplace, we have made a careful review of the literature, starting with studies that have laid the groundwork for understanding these phenomena to come gradually and to examine the latest literature in this regard, but not the literature which is specifically related to our case Kosovo. The review of the literature began with the description of the concept of psychological well-being, definitions, ways of measuring and ways of relieving stress in individuals affected by this problem. Psychosocial risk factors in the workplace were described in this context. We then described the prison health system in addition to the correctional system, describing a broad overview which outlines the main interventions that can be undertaken at the organizational level and at the individual level to prevent the consequences of work-related stress and reduce its level. . Then, we briefly highlighted the gap regarding scientific research on psychosocial factors operating in the work environment of prison health staff in our country, highlighting the usefulness and importance of undertaking such a study in Kosovo. Also, based on the scientific analysis we undertook, it was possible to quantitatively assess the average level of each of the psychosocial stress factors in the workplace of prison health staff.

\section{LITERATURE}

1. Adams Susan (2013), Forbes Magazine, 10 October 2013, Unhappy Employees Outnumber Happy Ones By Two To One Worldwide, 
2. Aristotle: The Nicomachean Ethics. New York: Oxford University Press; 1925.

3. Badrick Craig, 2016, Corrections Officer Among the Top Ten Most Dangerous Jobs in 2015,

4. Baer Ruth A. (2014). Practicing Happiness: How Mindfulness Can Free You From Psychological Traps and Help You Build the Life You Want, 2014.

5. Bottoms, E. Anthony. (1999). Interpersonal Violence and Social Order in Prisons. Crime \& Justice, The University of Chicago Press, Vol. 26, 205-281.

6. Brough, P. and Williams, J. (2007). "Managing occupational stress in a high-risk industry: Measuring the job demands of correctional officers". Criminal Justice and Behavior, Vol. 34 No. 4 pp. 555-567.

7. Cooper Cary L, Cooper Rachel D, Eaker Lzynn H. (1988) Living with stress. Harmonsworth: Pengium.

8. Coyle Andrew, Stern V (2004). Captive populations: prison health care.

9. Cullen, F., Link, B., Wolfe, N., \& Frank, J. (1985). The social dimensions of correctional officer stress.Justice Quarterly, 2, 505-533 https://www.researchgate.net/publication/251301206_The_Issue_of_Control_in_Jail_The_Effects_of_Profession alism_Detainee_Control_and_Administrative_Support_on_Job_Stress_Job_Satisfaction_and_Organizational_Co mmitment_among_Jail_Staff [accessed Nov 15 2018].

10. Deparatamenti Shëndetsor i Burgjeve, Ministria e Shndetësis, https://msh.rksgov.net/departamentet/departamenti-per-shendetesine-ne-burgje/

11. Dodge Rachel, Daly Annette, Huyton Jan, Sanders Lalage (2012). "The challenge of defining wellbeing". International Journal of Wellbeing.

12. Dowden C., Tellier C. (2004): Predicting work-related stress in correctional officers: a metaanalysis.

13. Europen Agency for Safety and Helath (EU-OSHA), Europen opinion poll on occupational safety and helath, 2013 ,

14. Europen Agency for Safety and Helath (EU-OSHA), Psychosocial risks and stres at work,

15. Ferrie, J.E. (2001). Is job insecurity harmful to health? Journal of the Royal Society of Medicine, 94, 71-76.

16. Gjocaj, Milazim (2015), Transferi i plotë i shërbimeve shëndetësore të burgjeve të kosovës nga ministria e drejtësisë në ministrinë e shëndetësisë sipas rekomandimeve të organizatës botërore të shëndetësisë; Doktorratura, Universiteti i Tiranës, Tiranë 2015

17. Institutit Kombëtar i Sigurisë dhe Shëndetit në Punë (NIOSH), 1999, Stress at Work, U.S.Department of Health and Human Services.

18. Ipsos, 2017, A Majority of Americans Have Experienced Mental Health Symptom(s) Over the Past Year, 3 May 2017, https://www.ipsos.com/sites/default/files/2017-05/MentalHealth-PR-2017-04-27-v1.pdf

19. Jaskowiak Raquel Caroline \& FontanaI Teresinha Rosane (2015), The work in prison: reflections on the health of prison officers http://www.scielo.br/pdf/reben/v68n2/0034-7167-reben-68-02-0235.pdf

20. Karasek Robert, Theorell Töres (1990). Healthy work: stress, productivity and the reconstruction of working life. New York, Basic Books.

21. Kristensen, T.S., Borg, V. (2003). Copenhagen Psychosocial Questionnaire - a questionnaire on psychosocial working conditions, health and well-being in three versions. E disponueshme në: http://www.arbejdsmiljoforskning.dk/ /media/Spoergeskemaer/copsoq/english-copsoq-2-ed-2003-pdf.pdf.

22. Kristensen, T.S., Hannerz, H., Høgh, A., Borg, V. (2005). The Copenhagen Psychosocial Questionnaire—a tool for the assessment and improvement of the psychosocial work environment. Work Environ Health, 31, 438-449. 
23. Kuhn Karl, 2010, Challenge of modern working life to mental well-being and social inclusion Workplace-related mental health problems - risks and prevention. Mental health and well-being at the workplace - protection and inclusion in challenging times, page 13.

24. Kunst, M. J. J. (2011). "Working in prisons: A critical review of stress in the occupation of correctional officers". In J. Langan-Fox \& C.L. Cooper (Eds.), Handbook of Stress in the Occupations (pp.241-283) Edward Elgar Publishing, Northampton.

25. Lamers, Sanne MA, Westerhof Gerben J, Glas Cees AW, Bohlmeijer Ernst T. (2015). The bidirectional relation between positive mental health and psychopathology in a longitudinal representative panel study, The Journal of Positive Psychology, 10 (2015), pp. 1-8.

26. Liebling, Alison. (2011). Distinctions and Distinctiveness in the Work of Prison Officers: Legitimacy and Authority Revisited. European Journal of Criminology, Vol. 8 (6), 484-499.

27. Lindfors P, Berntsson L, Lundberg U. Total workload as related to psychological well-being and symptoms in full-time employed female and male white-collar workers. Int J Behav Med. 2006;13:131-137.

28. Lovibond, P.F. \& Lovibond, S.H. (1995). "Depression Anxiety Stress Scales (DASS)". Psychology Foundation of Australia.

29. Marmot MG, Smith GD, Stansfeld S, Patel C, North F, Head J, White I, Brunner E, Feeney A.Lancet. (1991). Health inequalities among British civil servants: the Whitehall II study. Lancet, 337:1387-1393.

30. Marmot Michale, Bobak Martin (2005). Social and economic changes in health in Europe. East and West European Review, 13:15-32. http://www.euro.who.int/_data/assets/pdf_file/0003/98391/E93348.pdf

31. Marmot Michale, Wilkinson Reds. (2006). Social determinants of health. Oxford, Oxford University Press.

32. Marmot, M., Ferrie, J., Newman, K., Stansfeld, S. (2001). The contribution of job insecurity to socio-economic inequalities.

33. Medical Protection. 2015. 85\% of doctors have experienced mental health issues, reveals Medical Protection survey, Post date: 16/07/2015.

34. Meltzer, H., Bebbington, P., Brugha, T., Jenkins, R., McManus, S., Stansfeld, S. (2010). Job insecurity, socioeconomic circumstances and depression. Psychol Med, 40, 1401-7.

35. Miciel Joseph. (2008) Stress and the Effects of Working in a High Security Prison.

36. Ministri e Shëndetësisë, 2017, Praktikat Standarde të Veprimit, Procedurat e Funksionimit të Shërbimeve Shëndetësore në Burgje, MSH - Departamenti Shëndetësor i Burgje, 2017. https://msh.rks-gov.net/wpcontent/uploads/2013/11/1.-praktikat-standarde-te-veprimit-n\%c3\%ab-dshb.pdf

37. Ministria e Drejtësisë, https://md.rks-gov.net/page.aspx?id=1,86

38. Molleda Brings C, Muñiz Fernández A, Fresno Álvarez E, Cordero Martínez A, Díaz Rodríguez FJ, (2015), Influence of burnout on the health of prison workers, Rev ESP Sanid PEnit 2015; 17:64-76.

39. Morgan, R., Van Haveren, R. \& Pearson, C. (2002). "Correctional officer burnout: Further analyses". Criminal Justice and Behavior, Vol. 29 No 2, pp. 144-160.

40. National Institute of Justice, 24 July 2017, "Correctional Officer Safety and Wellness — What We Learned from the Research Literature,".

41. NEKORANEC Jaroslav \& KMOŠENA Miroslav, 2015, STRESS IN THE WORKPLACE - SOURCES, EFFECTS AND COPING STRATEGIES, Review of the Air Force Academy, No 1 (28) 2015, http://www.afahc.ro/ro/revista/2015_1/163.pdf 
42. Peggy A. Thoits. (2010). Stress and Health: Major Findings and Policy Implications, Journal of Health and Social Behavior, 51 (2010), pp. S41-S53,

43. Pia Schönfeld, Julia Brailovskaia, Angela Bieda, Xiao Chi Zhang, Jürgen Margraf. (2016). The effects of daily stress on positive and negative mental health: Mediation through self-efficacy, International Journal of Clinical and Health Psychology, 16 (2016), pp.

44. Restellini, Pierre, Jean (2008). Shëndetësia në burgje, Udhërrëfyes i Organizatës Botërore të Shëndetësisë mbi bazat e shëndetësisë në burgje, Problemet klinike dhe etika specifike për burgjet, faqe 33 .

45. RIGGIO, Ronald .E. (2003) .Introduction to Industrial/Organizational Psychology, Sixth Edition, 2013, Pearson Education. ISBN-13: 978-0-205-25499-6. ISBN-10: 0-205-25499-3

46. Rogers, John B. (2001). FOCUS I Survey and Final Report: A Summary of the Findings: Families Officers and Corrections Understanding Stress.

47. Ryff CD, Heidrich SM. Experience and well-being: Explorations on domains of life and how they matter. Int J Behav Dev. 1997;20:193-206.

48. Ryff CD, Singer BH. Best news yet on the six-factor model of well-being. Soc Sci Res. 2006;35:1103-1119.

49. Ryff, Carol D. (1989). "Happiness is everything, or is it? Explorations on the meaning of psychological wellbeing". Journal of Personality and Social Psychology. 57 (6): 1069-1081.

50. Sapountzi D, Lemonidou C. Nursing in Greece. Developments and prospects. Athens: Academy of Health Professions; 1994.

51. Schaufeli, W.B. and Peeters, M.C.W. (2000). "Job stress and burnout among correctional officers: A literature review". International Journal of Stress Management, Vol. 7 No. 1, pp. 19-48.

52. Siegrist Johannes, Starke Dagmar, Chandola Tarani, Godin Isabelle, Marmot Michael, Niedhammer Isabelle, Peter Richard. (2004). The measurement of effort-reward imbalance at work: European comparisons.Social Science and Medicine, 58:1483-1499.

53. Staff and Organization Support Programme (SOAP). (2010). Psychological Well - Being (22 Dec 2010).

54. Stanford University (2018), Psychological Wellbeing Scale.

55. Stansfeld Stephen, Head Jenny, Marmot Michael. (1998). Psychosocial work characteristics and social support as predictors ofSF-36 functioning: the Whitehall II study. Psychosomatic Medicine, 60:247-255.

56. Strauser DR, Lustig DC, Çıftçı A. Psychological well-being: Its relation to work personality, vocational identity, and career thoughts. J Psychol. 2008;142:21-35.

57. Shërbimi Korrektues i Kosovës, https://shkk.rks-gov.net

58. Tricia A Seifert. (2005). The Ryff scales of psychological well-being.

59. Tyler Patrick A, Ellison Rachel N. Sources of stress and psychological well-being in high-dependency nursing. J Adv Nurs 1994;19:469-76.

60. The cost of mental health problems. The fundamental fact, The Mental Health Foundation, UK, 2000 (www.mentalhealth.org.uk//ffcost.htm).

61. Udhzimi NICE, 2015. Workplace health: management practices, NICE guideline, Published: 24 June 2015. https://www.nice.org.uk/guidance/ng13/resources/workplace-health-management-practices-1837269751237

62. Weinrath, Maichael. (2016). Behind the Walls: Inmates and Correctional Officers on the State of Canadian Prisons. Vancouver: University of British Columbia Press. 